\title{
Singlet oxygen-mediated transformation of furans into aromatic nitrogen-containing polycycles in water
}

\author{
Dimitris Kalaitzakis, Tamsyn Montagnon, Georgios I. Ioannou, Eirini Antonatou, \\ and Georgios Vassilikogiannakis* \\ Department of Chemistry, University of Crete, Vasilika Vouton, 71003, Iraklion, Crete, Greece \\ E-mail: vasil@chemistry.uoc.gr
}

\section{Dedicated to Professor Michael Orfanopoulos in honor of his outstanding contribution to organic chemistry}

DOI: http://dx.doi.org/10.3998/ark.5550190.p008.973

\begin{abstract}
Using a sustainable, green and one-pot protocol, simple furans are transformed into complex aromatic nitrogen-bearing polycycles that are synthetically important. The reaction, which is performed in water, begins with the highly selective and mild photooxidation of the furan substrate with singlet oxygen.
\end{abstract}

Keywords: Singlet oxygen, furans, water, sustainable chemistry, green chemistry, indole, tryptamine, Pictet-Spengler

\section{Introduction}

Achieving greater sustainability in the practice and application of organic chemistry is currently a major driving force in the field. The search for new synthetic methods is especially motivated by this imperative. ${ }^{1}$ Sustainability in synthesis, however, has many facets each of which must be considered: these range from maximizing yields and atom/step/redox-economy, ${ }^{2-6}$ to reducing the use of toxic reagents and solvents. All the concepts are covered by the overlapping and goaldefining tenets of ideal synthesis ${ }^{7-9}$ and green chemistry. ${ }^{10,11}$ Within synthetic organic chemistry, perhaps, the most challenging area in which to succeed with these new ideas, is in the synthesis of polycyclic targets rich in heteroatoms. These types of compound represent popular targets usually as a result of, but not limited to, their possession of important biological activities. ${ }^{12}$ The reasons for the difficulties so often encountered when seeking a sustainable approach to these molecules are numerous and include: (1) the high reactivity of heteroatom-based functionalities to many reaction conditions means that protecting groups are heavily used ${ }^{13,14}$ with the 
consequence that many non-constructive concessionary steps ${ }^{8,9}$ are commonly relied upon; (2) when manipulating, particularly, oxygen-rich structures, non-strategic redox manipulations ${ }^{8,9}$ often represent indiscriminately-used default transformations; and (3) access to different oxidation states for heteroatom-based functionalities (by means of oxidation or reduction) is dominated by heavy metal-based reagents with toxicity issues and/or by reagents which exhibit poor atom-economy.

We seek solutions to these problems by looking for new ways to employ the atom-economic and green oxidant, singlet oxygen $\left({ }^{1} \mathrm{O}_{2}\right)$, in the construction of diverse and important molecular motifs and molecules. ${ }^{15-17}$ Beyond its many advantages as a green reagent, singlet oxygen is an ideal player in sustainable chemistry because it is both highly selective in its reactions, which eliminates the need for protecting groups and non-strategic redox manipulations, ${ }^{17}$ and because it readily initiates one pot reaction sequences that can accomplish dramatic increases in molecular complexity in a single operation. ${ }^{18-20}$ Recently, we have explored ways to include basic nitrogen components in such sequences, ${ }^{21-24}$ so that not only polyoxygenated, but also nitrogen-bearing, polycycles can be targeted. In a new method, ${ }^{22,23}$ we combined the singlet oxygenphotooxidation of simple furans with the introduction into the reaction sequence of both a basic nitrogen reactant and a Pictet-Spengler cyclisation; ${ }^{25-27}$ thus, affording in one operation various aromatic nitrogen containing-polycycles that are present in many natural products and other bioactive targets. This method, however, required the use of methanol and chlorinated solvents, neither of which can be part of a complete sustainable paradigm. Therefore, to improve the credentials of the method, in our investigation reported herein, we attempted to undertake the transformation in water - a task that was by no means simple to accomplish as the water would have to participate as a reactant, as well as the reaction solvent. In such a carefully balanced reaction sequence as this one, such a mechanistic disturbance might be expected to have a significant bearing on the outcome. Despite this concern, we successfully developed an improved green protocol for the one pot conversion of simple and readily accessible furans into complex aromatic nitrogen-containing polycycles, in water, using singlet oxygen.

\section{Results and Discussion}

The mechanistic rationale, which served as the basis for our investigation, is shown in Scheme 1. It shows how water is expected to participate as a reactant and why the use of water as solvent might cause a serious deviation from what had been accomplished previously. ${ }^{22-24}$

Singlet oxygen, generated photochemically, typically first undergoes a [4+2]-cycloaddition with the furan substrate to give an ozonide (not shown). It is reasonable to suggest that the solvent, in this case water, might open the ozonide adduct to give a hydroxy-hydroperoxy intermediate B. The regiochemistry of this opening is irrelevant, since both possibilities later converge, but has been shown as occurring at the most substituted of the two possible positions, as there is evidence, at least when methanol is the solvent, that this is the preferred site for the 
ozonide opening. ${ }^{28-30}$ The hydroxyl group derived from the molecule of water could then initiate a ring-opening/closing rearrangement to yield the unusual bis-hemiketal-endoperoxide $\mathbf{D}$.

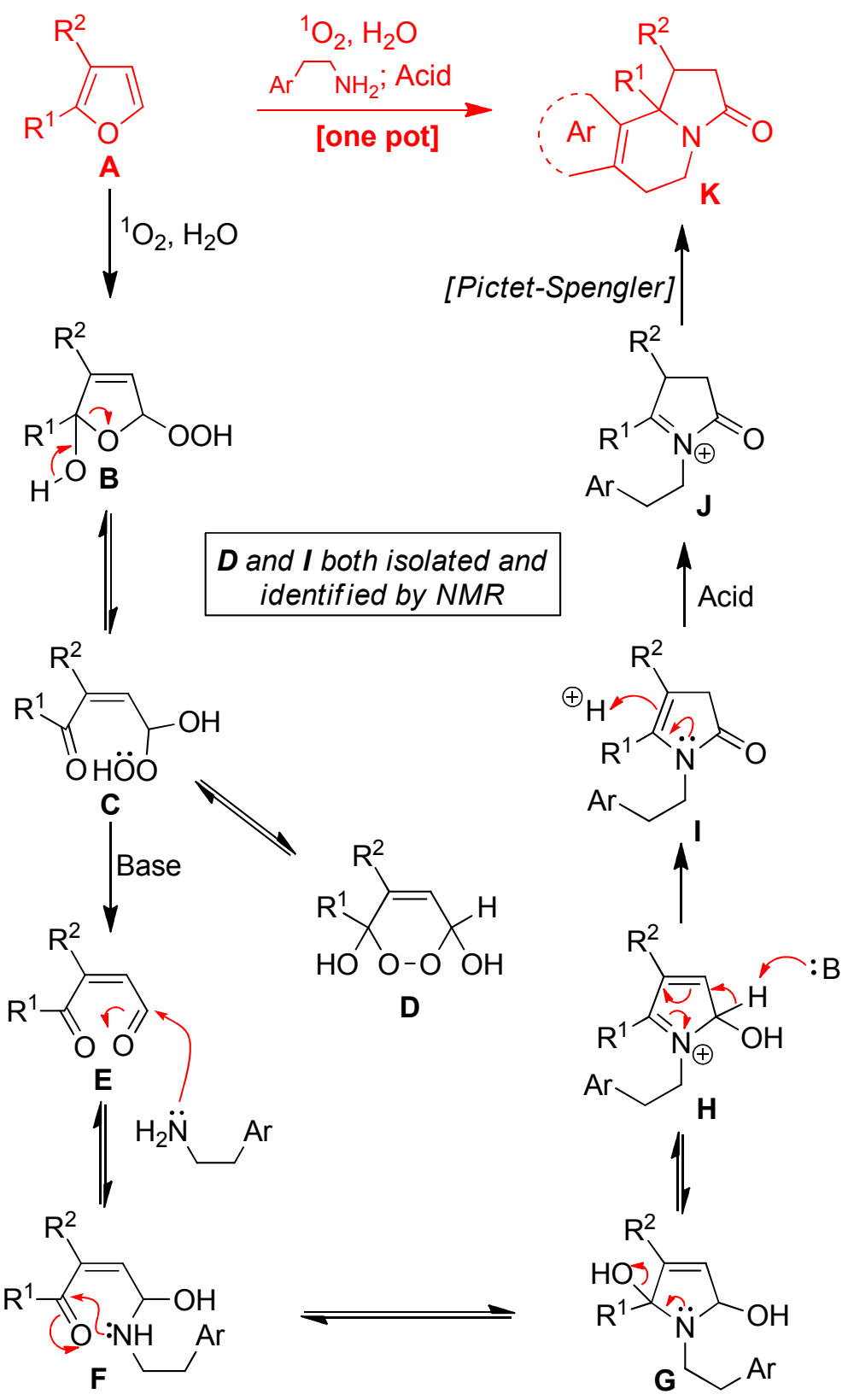

Scheme 1. Mechanistic rationale behind targeted cascade reaction sequence.

It should be noted here that in recent studies which share certain features with the current cascade reaction sequence, but which furnish entirely different products, we have found and characterized this intermediate. ${ }^{31}$ Under aqueous conditions, we propose that the equilibria between $\mathbf{B}, \mathbf{C}$ and $\mathbf{D}$ is sidelined by the collapse of the open chain hydroperoxy ketone $\mathbf{C}$ 
affording the unsaturated keto-aldehyde $\mathbf{E}$, which would in turn be the subject of an attack by the newly introduced amine $(\mathbf{E} \rightarrow \mathbf{F})$. It should be emphasized here that no reductant (such as the $\mathrm{Me}_{2} \mathrm{~S}$ utilized in such sequences ${ }^{21-24}$ ) shall be used as an additive, thus the new protocol will not only be undertaken in an environmentally benign solvent, but will also work in a more succinct manner and have a reduced number of additives/reagents than previous methods. A series of reorganizing equilibria could then afford cation $\mathbf{H}$, deprotonation of which affords the isolable, but fairly fragile, intermediate $\mathbf{I}$ that had been observed in previous studies. ${ }^{21-24}$ Treatment of this intermediate in situ with acid can lead to the formation of the $N$-acyliminium ion (NAI, ${ }^{32,33} \mathbf{J}$ ), which is the electrophile required for the Pictet-Spengler ${ }^{25-27}$ cyclisation $(\mathbf{J} \rightarrow \mathbf{K})$.

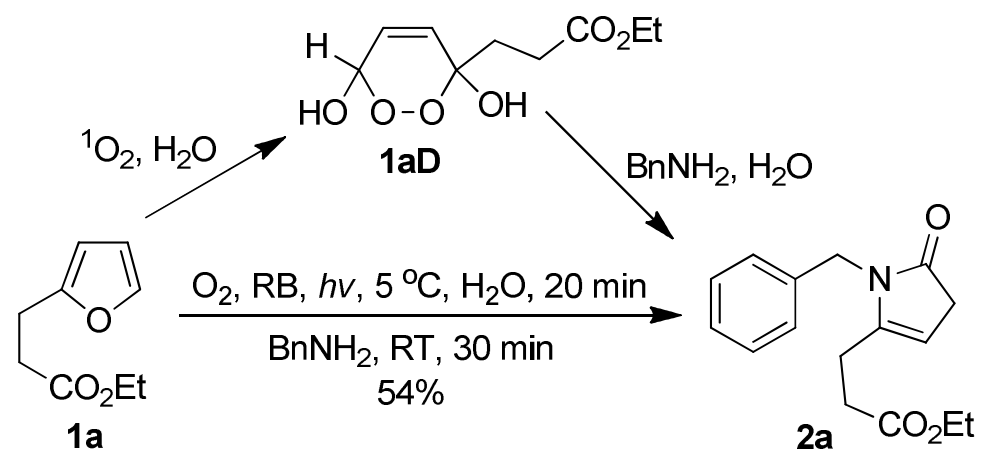

Scheme 2. Proof-of-principle experiment.

Since the last stages of this mechanistic analysis are common to the Pictet-Spengler reaction in methanol ${ }^{22}$ the first and most important task was to validate the early steps of the proposed sequence. To this end, the simple furan 1a was photooxygenated using our standard conditions: bubbling oxygen through the reaction solution containing catalytic rose Bengal at $5{ }^{\circ} \mathrm{C}$ while irradiating with visible spectrum light (Scheme 2). Worthy of note is that when water was the solvent, the irradiation time required was longer (20 - $40 \mathrm{~min})$ than that required in methanol (8 $\mathrm{min}$ ). After the reaction was complete (by tlc), as judged by the formation of intermediate 1aD whose structure was supported by NMR (see Expt.), benzylamine was added and the reaction was stirred for 30 mins at room temperature at which point the desired pyrrolidinone $\mathbf{2 a}$ formed. With this result in hand, we had obtained proof-of-principle for the new method; more specifically, we had demonstrated that in water and in the absence of a reductant, the desired pyrrolidinone of type I (Scheme 1) can be accessed.

To explore the scope of this mild transformation, a range of furan substrates was then examined for the one pot reaction sequence with tryptamine acting as coupling partner (Table 1). This time the sequence was not stopped at the pyrrolidinone stage; instead, an acid-promoted Pictet-Spengler reaction was used to terminate it to yield an interesting range of indolic polycycles (4a-e, Table 1). It should be noted that for the reaction of the furan 1e (Table 1, entry 5) $\mathrm{Me}_{2} \mathrm{~S}$ was added after the photooxygenation to reduce the stable spiro-hydroperoxide $\mathbf{5}$ to the 
corresponding spiro-hemiacetal 6a (Scheme 3); thus allowing the addition of tryptamine via its open form $\mathbf{6 b}(\mathbf{E} \rightarrow \mathbf{F}$, Scheme 1).

Table 1. Exploring the scope of the new cascade reaction sequence.

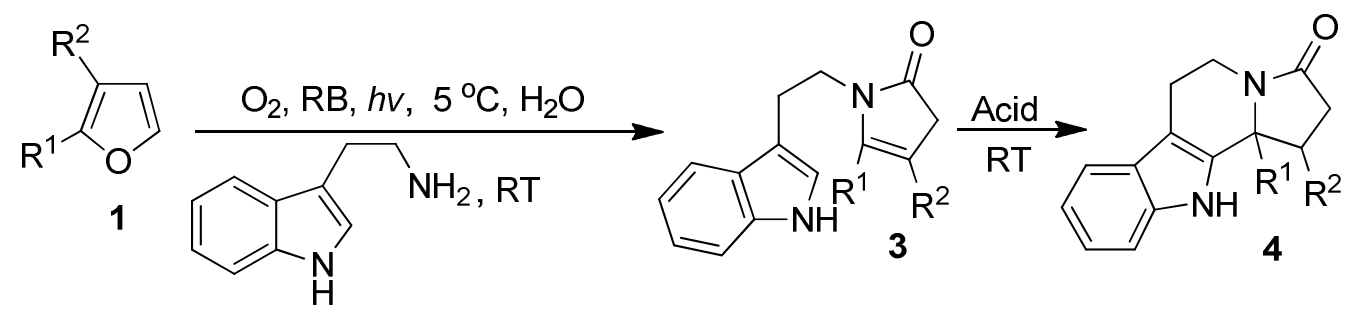

\begin{tabular}{|c|c|c|c|c|c|}
\hline Entry & Furan & Solvent & Tryptamine & Acid & $\begin{array}{l}\text { Product } \\
\text { yield }(\%)\end{array}$ \\
\hline 1 & & $\mathrm{H}_{2} \mathrm{O}$ & $\begin{array}{l}1 \text { equiv., } \\
0.5 \mathrm{~h}\end{array}$ & $\begin{array}{c}\text { TFA, } \\
1 \text { equiv., } 0.5 \mathrm{~h}\end{array}$ & $4 \mathbf{a}(58)$ \\
\hline 2 & & $\mathrm{H}_{2} \mathrm{O}$ & $\begin{array}{c}0.6 \text { equiv., } \\
0.5 \mathrm{~h}\end{array}$ & $\begin{array}{c}\text { TFA, } \\
0.7 \text { equiv., } 0.5 \mathrm{~h}\end{array}$ & $4 b(45)$ \\
\hline 3 & & $\mathrm{H}_{2} \mathrm{O}$ & $\begin{array}{l}0.7 \text { equiv., } \\
0.5 \mathrm{~h}\end{array}$ & $\begin{array}{c}\text { TFA, } \\
0.7 \text { equiv., } 0.5 \mathrm{~h}\end{array}$ & $4 \mathbf{c}(51)^{b}$ \\
\hline 4 & & $\begin{array}{c}\mathrm{H}_{2} \mathrm{O} / \mathrm{CH}_{3} \mathrm{CN} \\
9 / 1 \mathrm{v} / \mathrm{v}\end{array}$ & $\begin{array}{l}1 \text { equiv., } \\
0.5 \mathrm{~h}\end{array}$ & $\begin{array}{c}\text { TFA, } \\
1.2 \text { equiv., } 1 \mathrm{~h}\end{array}$ & $4 d(55)$ \\
\hline $5^{c}$ & & $\mathrm{H}_{2} \mathrm{O}$ & $\begin{array}{l}1.2 \text { equiv., } \\
1 \mathrm{~h}\end{array}$ & $\begin{array}{c}\text { PTSA, } \\
1 \text { equiv., } 1 \mathrm{~h}\end{array}$ & $4 e(60)$ \\
\hline
\end{tabular}

${ }^{a}$ Less equiv. of tryptamine were used since part of the volatile furans $\mathbf{1 b}$ and $\mathbf{1 c}$ evaporated during the bubbling of $\mathrm{O}_{2} \cdot{ }^{b}$ Isolated as a 6:4 cis/trans mixture of two diastereomers. ${ }^{c} \mathrm{Me}_{2} \mathrm{~S}(1$ equiv.) added after the photooxygenation.<smiles>CS[C@@H](CO)[C@H]1CCOC2(C=CC(O)O2)C1</smiles>

Scheme 3. Role of $\mathrm{Me}_{2} \mathrm{~S}$ in cascade reaction sequence that starts from furan 1e.

The developed protocol was simple and easy to execute. Furthermore, the yields can be described as good considering the increase in molecular complexity achieved from the sequence. As can be seen from Table 1, this oxidative reaction is mild and selective enough to accommodate various sensitive moieties, such as a primary iodide or a naked primary alcohol (and an aldehyde, vide infra). 


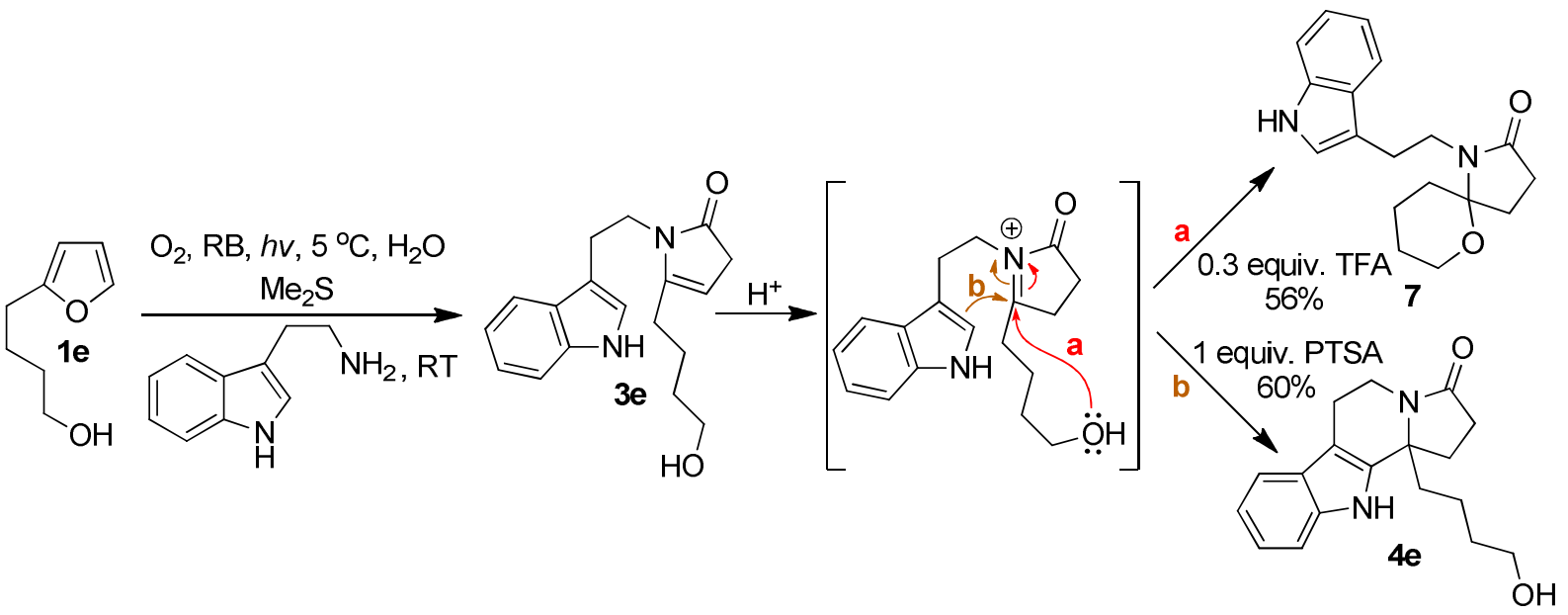

Scheme 4. Example illustrating the tunability of the method.

Such one pot reaction sequences become all the more powerful if they are controllable and can discriminate between reaction pathways when applied to substrates where two or more choices are open. The sequence developed here is tunable and selections over which reaction pathway a substrate follows upon reaction can be made, as illustrated by the example given in Scheme 4, where the type and quantity of acid used can lead to a switch in the reaction pathway. Thus, when the substrate was furan 1e, the use of a sub-equimolar amount of TFA gave spirocycle 7 (pathway a, Scheme 4), while the use of an equivalent of PTSA led to the fused polycycle 4e via the Pictet-Spengler reaction (pathway b).

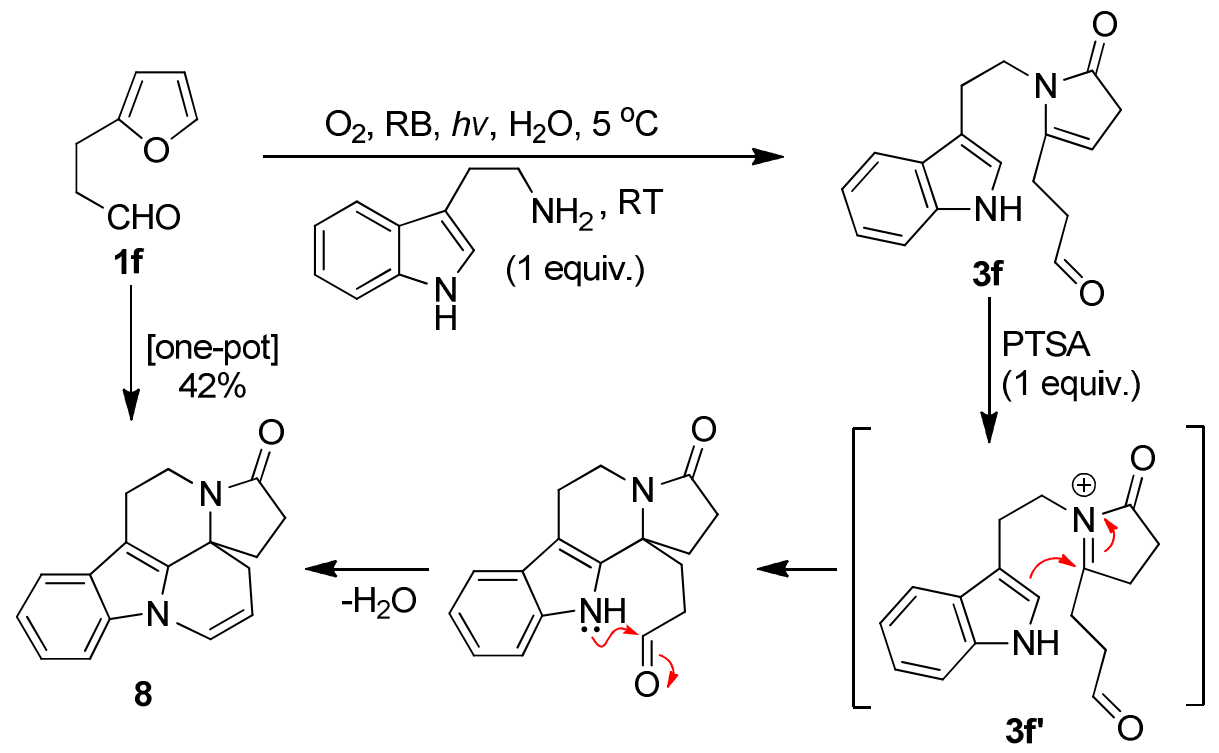

Scheme 5. Formation of pentacyclic compound $\mathbf{8}$. 
It was also of interest to explore the behavior of a substrate that bore an electrophilic aldehyde (-CHO) on its 2-alkyl side chain (1f, Scheme 5), to investigate the reactivity of the indole nucleus with the intermediate dielectrophile $N$-acyliminium ion (3f', Scheme 5). In this case, the Pictet-Spengler reaction was followed by a second cyclization with the aldehyde to afford, after dehydration, the polycyclic compound $\mathbf{8}$ (Scheme 5). Thus, the aldehyde moiety remained untouched throughout the cascade reaction sequence until it was needed to participate in the final electrophilic attack which completed the synthesis of a complex aromatic pentacycle 8 in a one pot process.

\section{Conclusions}

Simple and readily accessible furans, including some with fragile substituents, can be transformed into complex aromatic nitrogen-containing polycycles using a mild one pot protocol that scores highly on sustainability indices. In terms of green chemistry, ${ }^{10,11}$ and excluding the molecules that are incorporated in their totality in the product, an environmentally benign solvent (water) and oxidant (singlet oxygen) are used and the only compromises made (in terms both of atom efficiency and reagent safety - towards both humans and the environment) are the use of small amounts of TFA or PTSA to facilitate the last step of the cascade (the Pictet-Spengler cyclisation) and the use of minute amounts of a natural catalyst (rose Bengal) that has a toxicity profile sufficient to allow it to have in vivo human medical applications. ${ }^{34}$ Of course, singlet oxygen is used as a cytotoxic agent in photodynamic therapy ${ }^{35}$ (generated in situ, in vivo), so it obviously cannot be called a non-toxic reagent; however, as it is generated and used here the operator would never be exposed to the reagent because of its unique characteristics and short lifetime and it can, therefore, not exert any toxic effect. Its toxicity is completely nullified, and, furthermore, no residues remain after its use, toxic or otherwise. Finally, the reaction sequence involved combines a dramatic increase in molecular complexity in one operation (high stepeconomy $^{3-5}$ ) with excellent atom-economy ${ }^{2}$ and is thus very efficient. This new protocol is, therefore, an advance towards the ultimate goal of attaining ideal ${ }^{7-9}$ sustainable synthesis and joins other efforts made by us to achieve this very challenging target. ${ }^{36,37}$

\section{Experimental Section}

General. ${ }^{1} \mathrm{H}$ NMR spectra were recorded with a $500 \mathrm{MHz}$ Bruker spectrometer in $\mathrm{CDCl}_{3}$ solutions, and ${ }^{13} \mathrm{C}$ NMR spectra were recorded with a $125 \mathrm{MHz}$ Bruker spectrometer in $\mathrm{CDCl}_{3}$ solutions. HRMS data were recorded using an Agilent G6220A TOF-MS mass spectrometer. The irradiation was performed using a xenon Variac Eimac Cermax $300 \mathrm{~W}$ lamp. Compounds 1a, 1b and $\mathbf{1 c}$ are commercially available while $\mathbf{1 d},{ }^{24} \mathbf{1 e},{ }^{36}$ and $\mathbf{1 f}^{23}$ were prepared, as previously reported. 
General procedure. Substituted furans $(0.9 \mathrm{mmol}$ for 1a-c, 1e, 1f) were dissolved in water $(22.5$ $\mathrm{mL}, 40 \mathrm{mM}$ final concentration), or, in the case of $1 \mathbf{d}$ a mixture of $\mathrm{H}_{2} \mathrm{O} / \mathrm{CH}_{3} \mathrm{CN}(9: 1 \mathrm{v} / \mathrm{v}, 30 \mathrm{~mL}$, $30 \mathrm{mM}$ final concentration) was used. In the case of compounds $1 \mathbf{a}, \mathbf{1 c}$ and $\mathbf{1 d}$, the mixture was subjected to ultrasonic vibration until complete dissolution was achieved. Catalytic amounts of rose Bengal $\left(10^{-4} \mathrm{M}\right)$ were added to the solutions which were then cooled in an ice bath. Oxygen was gently bubbled through the solutions while they were irradiated with a xenon Variac Eimac Cermax $300 \mathrm{~W}$ lamp. The reactions were monitored by tlc (for compounds 1a, 1d-f) or by NMR (for compounds $\mathbf{1 b} \& \mathbf{1 c}$ ). After completion of the photooxidation (20 min for 1a-c \& 1e-f, 40 $\min$ for 1d) the solutions were warmed to $\mathrm{rt}$ and the appropriate amine $(0.9 \mathrm{mmol}$ of benzylamine for 1a, or tryptamine for $\mathbf{1 a}, \mathbf{1 d}, \mathbf{1 f}$, or $0.54 \mathrm{mmol}$ of tryptamine for $\mathbf{1 b}$, or 0.63 mmol of tryptamine for 1c, or $1.08 \mathrm{mmol}$ of tryptamine for $\mathbf{1 e}$ ) was added. In case of $1 \mathbf{e}$, before the addition of the amine, it was necessary to add $\mathrm{Me}_{2} \mathrm{~S}(0.9 \mathrm{mmol})$ and leave the mixture to stir at $\mathrm{rt}$ for $30 \mathrm{~min}$ (vide supra and Scheme 3). The reaction mixtures were then stirred at room temperature for the formation (observed by TLC) of the intermediate pyrrolidinone of type $\mathbf{2} \mathbf{a}$ or 3 (30 min for 1a-d, 1 f or $60 \mathrm{~min}$ for $\mathbf{1 e}$ ).

To verify its formation the pyrrolidinone 2a was isolated and characterized. The mixture was extracted with EtOAc $(2 \times 20 \mathrm{~mL})$, the combined organic layers were then concentrated in vacuo and the residue purified by flash column chromatography (silica gel neutralized with triethylamine, petroleum ether/EtOAc, 5:1).

In all the other cases the intermediate pyrrolidinones (3a-f) were treated in situ with the appropriate acid $(0.9 \mathrm{mmol}$ of TFA for $\mathbf{1 a}$, or $0.63 \mathrm{mmol}$ of TFA for $\mathbf{1 b}, \mathbf{c}$, or $1.08 \mathrm{mmol}$ of TFA for 1d, or $0.9 \mathrm{mmol}$ of PTSA for 1e,f). For the preparation of the spiro-adduct 7, TFA (0.27 mmol) was added. The reaction mixtures were stirred at $\mathrm{rt}$ for $30 \mathrm{~min}$ (or $60 \mathrm{~min}$ in case of compounds 1d,e). After the completion of the reactions, $\mathrm{NaCl}(300 \mathrm{mg})$ was added and the mixtures were extracted with EtOAc $(2 \times 20 \mathrm{~mL})$. The combined organic phases were concentrated in vacuo and the products were purified by flash column chromatography (silica gel, petroleum ether/EtOAc, 2:1 for $\mathbf{4 a}$ and $\mathbf{4 d}$; $1: 1$ for $\mathbf{4 b}, \mathbf{4 c}, \mathbf{7}$ and $\mathbf{8} ; 1: 3$ for $\mathbf{4 e}$ ).

To verify our mechanistic hypothesis, intermediate $\mathbf{1 a D}$ (starting furan 1a, Scheme 2) was isolated after photooxidation by extracting the mixture with EtOAc $(2 \times 20 \mathrm{~mL})$. The combined organic layers were concentrated in vacuo and the residue was purified by flash column chromatography (silica gel, petroleum ether/EtOAc, 1:1).

Ethyl 3-(3,6-dihydroxy-3,6-dihydro-1,2-dioxin-3-yl)propanoate (1aD). Isolated yield 36\%. The isolated yield is low because this fragile intermediate was not highly stable to column chromatography. ${ }^{1} \mathrm{H}$ NMR $\left(500 \mathrm{MHz}, \mathrm{CDCl}_{3}\right): \delta_{\mathrm{H}} 1.27(3 \mathrm{H}, \mathrm{t}, J 7.2 \mathrm{~Hz}), 2.05-2.09(1 \mathrm{H}, \mathrm{m})$, 2.17-2.23 (1H, m), 2.40-2.49 (2H, m), 4.11-4.19 (2H, m), $5.30(1 \mathrm{H}, \mathrm{d}, J 3.9 \mathrm{~Hz}), 5.97(1 \mathrm{H}, \mathrm{dd}, J$ $0.8,10.0 \mathrm{~Hz}), 6.11(1 \mathrm{H}, \mathrm{dd}, J 3.9,10.0 \mathrm{~Hz}) .{ }^{13} \mathrm{C} \mathrm{NMR}\left(125 \mathrm{MHz}, \mathrm{CDCl}_{3}\right): \delta_{\mathrm{C}} 14.0,29.2,32.1$, 61.2, 90.8, 96.4, 126.7, 129.0, 174.1. HRMS (TOF ESI): calcd for $\mathrm{C}_{9} \mathrm{H}_{13} \mathrm{O}_{6}: 217.0717$ [M-H]'; found: 217.0716 .

Ethyl 3-(1-benzyl-5-oxo-4,5-dihydro-1H-pyrrol-2-yl)propanoate (2a). Isolated yield $54 \%$. ${ }^{1} \mathrm{H}$ NMR $\left(500 \mathrm{MHz}, \mathrm{CDCl}_{3}\right): \delta_{\mathrm{H}} 1.23(3 \mathrm{H}, \mathrm{t}, J 7.1 \mathrm{~Hz}), 2.47(4 \mathrm{H}, \mathrm{s}), 3.09(2 \mathrm{H}, \mathrm{d}, J 2.5 \mathrm{~Hz}), 4.11$ 
$(2 \mathrm{H}, \mathrm{q}, J 7.1 \mathrm{~Hz}), 4.72(2 \mathrm{H}, \mathrm{s}), 4.94(1 \mathrm{H}, \mathrm{brs}), 7.20(2 \mathrm{H}, \mathrm{d}, J 7.0 \mathrm{~Hz}), 7.24(1 \mathrm{H}, \mathrm{t}, J 7.4 \mathrm{~Hz}), 7.31$ $(2 \mathrm{H}, \mathrm{dd}, J 7.0,7.4 \mathrm{~Hz}) .{ }^{13} \mathrm{C} \mathrm{NMR}\left(125 \mathrm{MHz}, \mathrm{CDCl}_{3}\right): \delta_{\mathrm{C}} 14.1,22.4,30.7,36.7,43.3,60.7,98.4$, 126.7 (2C), 127.4, 128.7 (2C), 137.4, 144.1, 172.0, 178.0. HRMS (TOF ESI): calcd for $\mathrm{C}_{16} \mathrm{H}_{20} \mathrm{NO}_{3}: 274.1438[\mathrm{M}+\mathrm{H}]^{+}$; found: 274.1438.

Ethyl 3-(3-oxo-2,3,5,6,11,11b-hexahydro-1 $H$-indolizino[8,7-b]indol-11b-yl)propanoate (4a). ${ }^{22}$ Isolated yield 58\%. ${ }^{1} \mathrm{H}$ NMR (500 MHz, $\left.\mathrm{CDCl}_{3}\right): \delta_{\mathrm{H}} 1.23(3 \mathrm{H}, \mathrm{t}, J 7.2 \mathrm{~Hz}), 2.19-2.40(5 \mathrm{H}$, m), 2.41-2.50 (2H, m), 2.63-2.70 $(1 \mathrm{H}, \mathrm{m}), 2.74-2.89(2 \mathrm{H}, \mathrm{m}), 3.08-3.16(1 \mathrm{H}, \mathrm{m}), 4.05-4.15(2 \mathrm{H}$, m), $4.50(1 \mathrm{H}, \mathrm{dd}, J 5.9,13.2 \mathrm{~Hz}), 7.12(1 \mathrm{H}, \mathrm{t}, J 7.2 \mathrm{~Hz}), 7.19(1 \mathrm{H}, \mathrm{t}, J 7.2 \mathrm{~Hz}), 7.33(1 \mathrm{H}, \mathrm{d}, J 8.0$ $\mathrm{Hz}), 7.47(1 \mathrm{H}, \mathrm{d}, J 7.8 \mathrm{~Hz}), 8.42(1 \mathrm{H}, \mathrm{brs}) .{ }^{13} \mathrm{C} \mathrm{NMR}\left(125 \mathrm{MHz}, \mathrm{CDCl}_{3}\right): \delta_{\mathrm{C}} 14.1,20.8,29.8$, 30.7, 30.8, 34.7, 35.8, 61.0, 62.0, 107.7, 111.0, 118.5, 119.8, 122.3, 126.5, 135.9, 136.1, 173.0, 173.9. HRMS (TOF ESI): calcd for $\mathrm{C}_{19} \mathrm{H}_{22} \mathrm{~N}_{2} \mathrm{NaO}_{3}: 349.1523[\mathrm{M}+\mathrm{Na}]^{+}$; found: 349.1520 .

11b-Methyl-5,6,11,11b-tetrahydro-1H-indolizino[8,7-b]indol-3(2H)-one $(\mathbf{4 b}) .^{22}$ Isolated yield 45\%. ${ }^{1} \mathrm{H}$ NMR $\left(500 \mathrm{MHz}, \mathrm{CDCl}_{3}\right): \delta_{\mathrm{H}} 1.59(3 \mathrm{H}, \mathrm{s}), 2.13-2.20(1 \mathrm{H}, \mathrm{m}), 2.27-2.32(1 \mathrm{H}, \mathrm{m}), 2.46$ $(1 \mathrm{H}$, ddd, $J 1.8,9.6,11.4 \mathrm{~Hz}), 2.63-2.71(1 \mathrm{H}, \mathrm{m}), 2.75-2.88(2 \mathrm{H}, \mathrm{m}), 3.09(1 \mathrm{H}, \mathrm{td}, J 5.5,11.9$ $\mathrm{Hz}), 4.46(1 \mathrm{H}, \mathrm{dd}, J 5.1,13.0 \mathrm{~Hz}), 7.10(1 \mathrm{H}, \mathrm{dd}, J 7.1,7.8 \mathrm{~Hz}), 7.16(1 \mathrm{H}, \mathrm{ddd}, J 1.0,7.1,8.0 \mathrm{~Hz})$, $7.33(1 \mathrm{H}, \mathrm{d}, J 8.0 \mathrm{~Hz}), 7.46(1 \mathrm{H}, \mathrm{d}, J 7.8 \mathrm{~Hz}), 8.64(1 \mathrm{H}, \mathrm{brs}) .{ }^{13} \mathrm{C} \mathrm{NMR}\left(125 \mathrm{MHz}, \mathrm{CDCl}_{3}\right): \delta_{\mathrm{C}}$ 21.1, 25.3, 30.7, 32.8, 34.9, 59.5, 106.6, 111.0, 118.4, 119.6, 122.0, 126.6, 136.1, 137.8, 172.8 ppm. HRMS (TOF ESI): calcd for $\mathrm{C}_{15} \mathrm{H}_{17} \mathrm{~N}_{2} \mathrm{O}: 241.1335[\mathrm{M}+\mathrm{H}]^{+}$; found: 241.1337.

1,11b-Dimethyl-5,6,11,11b-tetrahydro- $1 H$-indolizino[8,7-b]indol-3(2H)-one $(4 c){ }^{22}$ Isolated in $51 \%$ yield as a 6:4 cis/trans mixture of inseparable diastereomers. The fact that the cis compound is the major one in the isolated mixture of the two diastereoisomers was confirmed by comparison with the known in the literature ${ }^{38} \beta$-carboline (cis diastereoisomer). ${ }^{1} \mathrm{H}$ NMR (500 $\left.\mathrm{MHz}, \mathrm{CDCl}_{3}\right): \delta_{\mathrm{H}} 0.74(3 \mathrm{H}$ of trans, d, J 7.0 Hz), $1.36(3 \mathrm{H}$ of cis, d, $J 6.6 \mathrm{~Hz}), 1.45(3 \mathrm{H}$ of cis, s), $1.58(3 \mathrm{H}$ of trans, s), $2.10(1 \mathrm{H}$ of trans, d, $J 16.5 \mathrm{~Hz}), 2.31-2.35(1 \mathrm{H}$ of $c i s, \mathrm{~m}), 2.44-2.57(2 \mathrm{H}$ of cis plus $1 \mathrm{H}$ of trans, m), 2.74-2.87 (2H of cis plus $2 \mathrm{H}$ of trans, $\mathrm{m}$ ), 2.92-3.06 (1H of cis plus $1 \mathrm{H}$ of trans, m), 4.44-4.52 (1H of cis plus $1 \mathrm{H}$ of trans, $\mathrm{m}$ ), 7.13 (1H of cis plus $1 \mathrm{H}$ of trans, $\mathrm{dd}, J$ 7.2, 7.7 Hz), 7.16-7.22 (1H of cis plus $1 \mathrm{H}$ of trans, m), $7.35(1 \mathrm{H}$ of trans, d, $J 8.0 \mathrm{~Hz}), 7.36(1 \mathrm{H}$ of cis, d, J $8.0 \mathrm{~Hz}), 7.49(1 \mathrm{H}$ of cis, d, $J 7.7 \mathrm{~Hz}), 7.50(1 \mathrm{H}$ of trans, d, $J 7.7 \mathrm{~Hz}), 8.10(1 \mathrm{H}$ of cis, brs), 8.24 (1H of trans, brs). ${ }^{13} \mathrm{C}$ NMR $\left(125 \mathrm{MHz}, \mathrm{CDCl}_{3}\right): \delta_{\mathrm{C}} 14.8$ (cis), 17.4 (trans), 19.3 (cis), 21.3 (trans), 21.4 (cis), 25.1 (trans), 34.9 (cis), 35.2 (trans), 37.9 (trans), 38.7 (cis), 39.1 (cis), 39.4 (trans), 61.6 (cis), 63.4 (trans), 107.1 (cis), 109.3 (trans), 110.9 (trans), 111.0 (cis), 118.4 (trans), 118.5 (cis), 119.7 (trans), 119.9 (cis), 122.1 (trans), 122.2 (cis), 126.6 (cis plus trans), 134.7 (trans), 136.0 (trans), 136.1 (cis), 137.8 (cis), 171.9 (cis), 172.1 (trans). HRMS (TOF ESI): calcd for $\mathrm{C}_{16} \mathrm{H}_{19} \mathrm{~N}_{2} \mathrm{O}: 255.1492[\mathrm{M}+\mathrm{H}]^{+}$; found: 255.1491 .

11b-(3-Iodopropyl)-5,6,11,11b-tetrahydro- $1 H$-indolizino[8,7-b]indol-3(2H)-one (4d).

Isolated yield 55\%. ${ }^{1} \mathrm{H}$ NMR $\left(500 \mathrm{MHz}, \mathrm{CDCl}_{3}\right): \delta_{\mathrm{H}} 1.82-1.90(1 \mathrm{H}, \mathrm{m}), 1.90-2.00(1 \mathrm{H}, \mathrm{m}), 2.01-$ $2.14(2 \mathrm{H}, \mathrm{m}), 2.21-2.27(1 \mathrm{H}, \mathrm{m}), 2.34-2.40(1 \mathrm{H}, \mathrm{m}), 2.48(1 \mathrm{H}, \mathrm{ddd}, J 2.5,10.2,17.0 \mathrm{~Hz}), 2.62-$ $2.71(1 \mathrm{H}, \mathrm{m}), 2.80(1 \mathrm{H}, \mathrm{dd}, J 5.0,15.4 \mathrm{~Hz}), 2.82-2.92(1 \mathrm{H}, \mathrm{m}), 3.14(2 \mathrm{H}, \mathrm{t}, J 6.6 \mathrm{~Hz}), 3.11-3.19$ $(1 \mathrm{H}, \mathrm{m}), 4.53(1 \mathrm{H}, \mathrm{dd}, J 5.8,13.2 \mathrm{~Hz}), 7.12(1 \mathrm{H}, \mathrm{t}, J 7.4 \mathrm{~Hz}), 7.19(1 \mathrm{H}, \mathrm{dd}, J$ 8.1, $7.1 \mathrm{~Hz}), 7.34$ $(1 \mathrm{H}, \mathrm{d}, J 8.1 \mathrm{~Hz}), 7.48(1 \mathrm{H}, \mathrm{d}, J 7.8 \mathrm{~Hz}), 8.63(1 \mathrm{H}, \mathrm{brs}) .{ }^{13} \mathrm{C} \mathrm{NMR}\left(125 \mathrm{MHz}, \mathrm{CDCl}_{3}\right): \delta_{\mathrm{C}} 6.1$, 
20.9, 28.1, 30.6, 31.0, 35.8, 40.7, 62.1, 107.1, 111.1, 118.4, 119.8, 122.2, 126.5, 136.1, 136.7, 173.8. HRMS (TOF ESI): calcd for $\mathrm{C}_{17} \mathrm{H}_{20} \mathrm{IN}_{2} \mathrm{O}: 395.0615[\mathrm{M}+\mathrm{H}]^{+}$; found: 395.0616 .

11b-(4-Hydroxybutyl)-5,6,11,11b-tetrahydro- $1 H$-indolizino $[8,7-b]$ indol-3(2H)-one $(4 \mathrm{e}){ }^{24}$

Isolated yield 60\%. ${ }^{1} \mathrm{H}$ NMR $\left(500 \mathrm{MHz}, \mathrm{CDCl}_{3}\right): \delta_{\mathrm{H}} 1.40-1.60(4 \mathrm{H}, \mathrm{m}), 1.86-2.02(2 \mathrm{H}, \mathrm{m}), 2.16$ $(1 \mathrm{H}, \mathrm{q}, J 10.2 \mathrm{~Hz}), 2.31-2.46(3 \mathrm{H}, \mathrm{m}), 2.60-2.68(1 \mathrm{H}, \mathrm{m}), 2.77(1 \mathrm{H}, \mathrm{dd}, J 5.0,15.3 \mathrm{~Hz}), 2.80-2.89$ $(1 \mathrm{H}, \mathrm{m}), 3.13(1 \mathrm{H}, \mathrm{td}, J 5.2,12.4 \mathrm{~Hz}), 3.62(2 \mathrm{H}, \mathrm{t}, J 5.6 \mathrm{~Hz}), 4.47(1 \mathrm{H}, \mathrm{dd}, J$ 6.1, $13.1 \mathrm{~Hz}), 7.11$ $(1 \mathrm{H}, \mathrm{t}, J 7.4 \mathrm{~Hz}), 7.17(1 \mathrm{H}, \mathrm{t}, J 7.5 \mathrm{~Hz}), 7.32(1 \mathrm{H}, \mathrm{d}, J 8.0 \mathrm{~Hz}), 7.46(1 \mathrm{H}, \mathrm{d}, J 7.7 \mathrm{~Hz}), 8.50(1 \mathrm{H}$, brs). ${ }^{13} \mathrm{C}$ NMR $\left(125 \mathrm{MHz}, \mathrm{CDCl}_{3}\right): \delta_{\mathrm{C}} 20.7,21.0,30.4,31.1,32.6,35.6,39.7,62.2,62.6,106.9$, 111.0, 118.4, 119.7, 122.1, 126.6, 136.1, 137.3, 173.7. HRMS (TOF ESI): calcd for $\mathrm{C}_{18} \mathrm{H}_{22} \mathrm{~N}_{2} \mathrm{NaO}_{2}: 321.1573[\mathrm{M}+\mathrm{Na}]^{+}$; found: 321.1575 .

1-(2-(1H-Indol-3-yl)ethyl)-6-oxa-1-azaspiro[4.5]decan-2-one (7). ${ }^{24}$

Isolated yield 56\%. ${ }^{1} \mathrm{H}$ NMR $\left(500 \mathrm{MHz}, \mathrm{CDCl}_{3}\right): \delta_{\mathrm{H}} 1.48-1.69(4 \mathrm{H}, \mathrm{m}), 1.82-1.92(3 \mathrm{H}, \mathrm{m}), 2.28-$ $2.39(2 \mathrm{H}, \mathrm{m}), 2.52(1 \mathrm{H}, \mathrm{ddd}, J 7.3,9.9,17.3 \mathrm{~Hz}), 2.98-3.04(1 \mathrm{H}, \mathrm{m}), 3.08-3.16(1 \mathrm{H}, \mathrm{m}), 3.51-$ $3.57(2 \mathrm{H}, \mathrm{m}), 3.63-3.70(1 \mathrm{H}, \mathrm{m}), 3.88-3.94(1 \mathrm{H}, \mathrm{m}), 7.06(1 \mathrm{H}, \mathrm{d}, J 2.0 \mathrm{~Hz}), 7.13(1 \mathrm{H}, \mathrm{td}, J 1.0$, $8.0 \mathrm{~Hz}), 7.19(1 \mathrm{H}, \mathrm{td}, J 1.0,7.9 \mathrm{~Hz}), 7.36(1 \mathrm{H}, \mathrm{d}, J 8.0 \mathrm{~Hz}), 7.71(1 \mathrm{H}, \mathrm{d}, J 7.9 \mathrm{~Hz}), 8.09(1 \mathrm{H}$, brs). ${ }^{13} \mathrm{C}$ NMR $\left(125 \mathrm{MHz}, \mathrm{CDCl}_{3}\right): \delta_{\mathrm{C}} 20.3,25.0,25.3,26.9,28.8,33.7,40.4,64.1,93.1,111.1$, $113.3,118.8,119.0,121.7,121.9,127.5,136.2$, 175.4. HRMS (TOF ESI): calcd for $\mathrm{C}_{18} \mathrm{H}_{22} \mathrm{~N}_{2} \mathrm{NaO}_{2}: 321.1573[\mathrm{M}+\mathrm{Na}]^{+}$; found: 321.1576 .

\section{1,2,5,6-Tetrahydroindolo[3,2,1-de]pyrrolo[1,2-j][1,5]naphthyridin-4(7H)-one (8)}

Isolated yield $42 \% .{ }^{1} \mathrm{H}$ NMR $\left(500 \mathrm{MHz}, \mathrm{CDCl}_{3}\right): \delta_{\mathrm{H}} 1.91-1.99(1 \mathrm{H}, \mathrm{m}), 2.39(1 \mathrm{H}, \mathrm{dd}, J 6.0,15.8$ $\mathrm{Hz}), 2.41-2.45(1 \mathrm{H}, \mathrm{m}), 2.47(1 \mathrm{H}, \mathrm{dd}, J 8.7,16.6 \mathrm{~Hz}), 2.60(1 \mathrm{H}, \mathrm{dd}, J 7.9,12.2 \mathrm{~Hz}), 2.71-2.85$ $(4 \mathrm{H}, \mathrm{m}), 4.46-4.52(1 \mathrm{H}, \mathrm{m}), 5.25(1 \mathrm{H}, \mathrm{ddd}, J 2.6,6.0,7.6 \mathrm{~Hz}), 7.05(1 \mathrm{H}, \mathrm{dd}, J 2.2,7.6 \mathrm{~Hz}), 7.13-$ $7.18(1 \mathrm{H}, \mathrm{m}), 7.22-7.26(1 \mathrm{H}, \mathrm{m}), 7.39(1 \mathrm{H}, \mathrm{d}, J 8.1 \mathrm{~Hz}), 7.49-7.52(1 \mathrm{H}, \mathrm{m}) .{ }^{13} \mathrm{C} \mathrm{NMR}(125 \mathrm{MHz}$, $\left.\mathrm{CDCl}_{3}\right): \delta_{\mathrm{C}} 22.5,30.7,31.1,33.2,37.1,58.2,107.4,109.1,109.6,119.1,120.8,122.6,124.3$, 128.2, 135.6, 136.1, 175.2. HRMS (TOF ESI): calcd for $\mathrm{C}_{17} \mathrm{H}_{17} \mathrm{~N}_{2} \mathrm{O}: 265.1336[\mathrm{M}+\mathrm{H}]^{+}$; found: 265.1332 .

\section{Acknowledgements}

The research leading to these results has received funding from the European Research Council under the European Union's Seventh Framework Programme (FP7/2007-2013)/ERC Grant Agreement No. 277588 as well from the European Union's Seventh Framework Programme (FP7/2007-2013)/Marie Curie ITN Grant Agreement No. 316975.

\section{References}

1. New Methodologies and Techniques for a Sustainable Organic Chemistry, Mordini, A; Faigl, F. Eds.; Springer: Dordrecht, 2008, Nato Science Series II, Vol. 246, pp 1-174. 
2. Trost, B. M. Science 1991, 254, 1471.

http://dx.doi.org/10.1126/science.1962206

3. Wender, P. A. Tetrahedron 2013, 69, 7529.

http://dx.doi.org/10.1016/j.tet.2013.06.004

4. Wender, P. A.; Verma, V. A.; Paxton, T. J.; Pillow, T. H. Acc. Chem. Res. 2008, 41, 40. http://dx.doi.org/10.1021/ar700155p

5. Wender, P. A.; Miller, B. L. In Organic Synthesis: Theory and Applications; T. Hudlicky Eds.; JAI: Greenwich, 1993; Vol. 2, pp 27-66.

6. Burns, N. Z.; Baran, P. S.; Hoffmann, R. W. Angew. Chem. Int. Ed. 2009, 48, 2854.

http://dx.doi.org/10.1002/anie.200806086

7. Hendrickson, J. B. J. Am. Chem. Soc. 1975, 97, 5784.

http://dx.doi.org/10.1021/ja00853a023

8. Newhouse, T.; Baran, P. S.; Hoffmann, R. W. Chem. Soc. Rev. 2009, 38, 3010. http://dx.doi.org/10.1039/b821200g

9. Gaich, T.; Baran, P. S. J. Org. Chem. 2010, 75, 4657. http://dx.doi.org/10.1021/jo1006812

10. Anastas, P. T.; Warner, J. C. In Green Chemistry: Theory and Practice; Oxford University Press: USA, 2000.

11. Sheldon, R. A. Chem. Commun. 2008, 3352.

http://dx.doi.org/10.1039/b803584a

12. Taylor, R. D.; MacCoss, M.; Lawson, A. D. G. J. Med. Chem. 2014, 57, 5845. http://dx.doi.org/10.1021/jm4017625

13. Hoffmann, R. W. Synthesis 2006, 3531. http://dx.doi.org/10.1055/s-2006-950311

14. Young, I. S.; Baran, P. S. Nat. Chem. 2009, 1, 193. http://dx.doi.org/10.1038/nchem.216

15. Montagnon, T.; Noutsias, D.; Alexopoulou, I.; Tofi, M.; Vassilikogiannakis, G. Org. Biomol. Chem. 2011, 9, 2031. http://dx.doi.org/10.1039/c0ob00952k

16. Montagnon, T.; Tofi, M.; Vassilikogiannakis, G. Acc. Chem. Res. 2008, 41, 1001. http://dx.doi.org/10.1021/ar800023v

17. Montagnon, T; Kalaitzakis, D.; Triantafyllakis, M.; Stratakis, M.; Vassilikogiannakis, G. Chem. Commun. 2014, 50, 15480. http://dx.doi.org/10.1039/C4CC02083A

18. Triantafyllakis, M.; Tofi, M.; Montagnon, T.; Kouridaki, A; Vassilikogiannakis, G. Org. Lett. 2014, 16, 3150.

http://dx.doi.org/10.1021/ol501301w

19. Kouridaki, A.; Montagnon, T.; Kalaitzakis, D.; Vassilikogiannakis, G. Org. Biomol. Chem. 2013, 11, 537.

http://dx.doi.org/10.1039/c2ob27158c 
20. Vassilikogiannakis, G.; Alexopoulou, I.; Tofi, M.; Montagnon, T. Chem. Commun. 2011, 47, 259.

http://dx.doi.org/10.1039/c0cc01341b

21. Kalaitzakis, D.; Montagnon, T.; Alexopoulou I.; Vassilikogiannakis, G. Angew. Chem. Int. Ed. 2012, 51, 8868 .

http://dx.doi.org/10.1002/anie.201204419

22. Kalaitzakis, D.; Montagnon, T.; Antonatou, E.; Bardají, N.; Vassilikogiannakis, G. Chem. Eur. J. 2013, 19, 10119. http://dx.doi.org/10.1002/chem.201301571

23. Kalaitzakis, D.; Montagnon, T.; Antonatou E.; Vassilikogiannakis, G. Org. Lett. 2013, 15, 3714.

http://dx.doi.org/10.1021/ol401582e

24. Kalaitzakis, D.; Antonatou, E.; Vassilikogiannakis, G. Chem. Commun. 2014, 50, 400. http://dx.doi.org/10.1039/c3cc47690a

25. Pictet, A.; Spengler, T. Ber. Dtsch. Chem. Ges. 1911, 44, 2030.

http://dx.doi.org/10.1002/cber.19110440309

26. Cox, E. D.; Cook, J. M. Chem. Rev. 1995, 95, 1797.

http://dx.doi.org/10.1021/cr00038a004

27. Stöckigt, J.; Antonchick, A. P.; Wu, F.; Waldmann, H. Angew. Chem. Int. Ed. 2011, 50, 8538 .

http://dx.doi.org/10.1002/anie.201008071

28. Foote, C. S.; Wuesthoff, M. T.; Wexler, S.; Burstain, I. G.; Denny, R.; Schenck, G. O.; Schulte-Elte, K. H. Tetrahedron 1967, 23, 2583.

http://dx.doi.org/10.1016/0040-4020(67)85123-8

29. Gollnick, K.; Griesbeck, A. Tetrahedron 1985, 41, 2057.

http://dx.doi.org/10.1016/S0040-4020(01)96576-7

30. Feringa, B. L. Recl. Trav. Chim. Pays-Bas 1987, 106, 469. http://dx.doi.org/10.1002/rec1.19871060902

31. Kalaitzakis, D.; Triantafyllakis, M.; Alexopoulou I.; Sofiadis, M.; Vassilikogiannakis, G. Angew. Chem. Int. Ed. 2014, 53, 13201.

http://dx.doi.org/10.1002/anie.201407477

32. Speckamp, W. N.; Hiemstra, H. Tetrahedron 1985, 41, 4367.

http://dx.doi.org/10.1016/S0040-4020(01)82334-6

33. Maryanoff, B. E.; Zhang, H.-C.; Cohen, J. H.; Turchi, I. J.; Maryanoff, C. A. Chem. Rev. 2004, 104, 1431.

http://dx.doi.org/10.1021/cr0306182

34. Foote, M. C.; Burmeister, B. H.; Thomas, J.; Mark, S. B. Melanoma Research 2010, 20, 48. http://dx.doi.org/10.1097/CMR.0b013e328331caa2 
35. Frei, A.; Rubbiani, R.; Tubafard, S.; Blacque, O.; Anstaett, P.; Felgenträger, A.; Maisch, T.; Spiccia, L.; Gasser, G. J. Med. Chem. 2014, 57, 7280.

http://dx.doi.org/10.1021/jm500566f

36. Noutsias, D.; Alexopoulou, I.; Montagnon, T.; Vassilikogiannakis, G. Green Chem. 2012, 14, 601.

http://dx.doi.org/10.1039/c2gc16397g

37. Kouridaki, A.; Montagnon, T.; Tofi, M.; Vassilikogiannakis, G. Org. Lett. 2012, 14, 2374. http://dx.doi.org/10.1021/o13007937

38. Holloway, C. A.; Muratore, M. E.; Storer, R. I.; Dixon, D. J. Org. Lett. 2010, 12, 4720. http://dx.doi.org/10.1021/ol101651t 